\title{
Wheat straw mulch improves summer maize productivity and soil properties
}

\author{
Mehmood Ali Noor, Muhammad Mohsin Nawaz, Wei Ma, Ming Zhao \\ Institute of Crop Sciences, Chinese Academy of Agricultural Sciences, Key Laboratory of Crop Physiology \\ and Ecology, Ministry of Agriculture, Beijing, China
}

Highlights

- Wheat straw mulch improved maize grain yield by approx. $18 \%$ mainly by increased kernel numbers per ear.

Maize growth attributes and SPAD values were improved under mulch treatment compared to no-mulch.

- Straw mulching helped in maintaining comparatively higher soil moisture content $(\sim 2 \%)$ and reduced the soil temperature $\left(\sim 1.72^{\circ} \mathrm{C}\right)$ during the crop growth period.

\begin{abstract}
Crop residue mulch in agricultural systems preserves soil health and improves crop productivity through its moderating influence on soil temperature regime and enhanced moisture retention. Therefore, a field experiment was conducted to determine the changes in soil properties and grain yield of irrigated summer maize in response to wheat straw mulching in the Northern maize region in China. The treatments investigated were: i) application of wheat straw mulch $\left(5000 \mathrm{~kg} \mathrm{ha}^{-1}\right)$; and ii) no-mulch application (control). Maize growth and yield attributes were determined during various growth stages, and soil hydro-thermal properties were recorded for two depths (0-15 and 15-30 cm). Straw mulch increased the yield by $18 \%$ and also increased total dry biomass yield by $20 \%$, compared to no-mulch. Yield increment was attributed to the increased number of ears per area and kernels
\end{abstract}

Correspondence: Mehmood Ali Noor and Wei Ma, Institute of Crop Sciences, Chinese Academy of Agricultural Sciences, Key Laboratory of Crop Physiology and Ecology, Ministry of Agriculture, Beijing, 100081, China.

E-mail:mehmood2017@gmail.com; mawei02@caas.cn

Key words: Crop residue; mulching; maize yield; soil temperature; soil moisture.

Acknowledgements and funding: this work was supported by the National Key Research and Development Program of China (2017YFD0301307and 2018YFD020060), the National Natural Science Foundation of China (31971851), and the earmarked fund for China Agriculture Research System (CARS-02-12).

Received for publication: 17 March 2020.

Revision received: 17 September 2020.

Accepted for publication: 17 September 2020

${ }^{(C)}$ Copyright: the Author(s), 2021

Licensee PAGEPress, Italy

Italian Journal of Agronomy 2021; 16:1623

doi:10.4081/ija.2020.1623

This article is distributed under the terms of the Creative Commons Attribution Noncommercial License (by-nc 4.0) which permits any noncommercial use, distribution, and reproduction in any medium, provided the original author(s) and source are credited. number per ear. The effect on thousand kernels weight was found non-significant. Vigorous maize growth was observed under straw mulch treatment, having greater leaf area index, unit leaf rate, leaf area duration, and crop growth rate. Similarly, the dry matter partitioning for maize kernels was greater in mulch treatment. At the late reproductive stages (R3 and R5), SPAD values for ear and below-ear leaves were higher under mulch treatment. Straw mulch decreased the daytime soil temperature by 1.9 and $1.5^{\circ} \mathrm{C}$ on average for $0-15$ and $15-30 \mathrm{~cm}$ soil layers, respectively. Whereas, the soil moisture content increased about 2.5\% (0-15 cm) and 3\% (15$30 \mathrm{~cm}$ ) under the mulch treatment. In crux, leftover crop residue application as mulch in irrigated maize could be a sustainable agronomic option to increase the crop productivity.

\section{Introduction}

The Huang-Huai-Hai (HHH) region in China is one of the largest agricultural production areas in North of the country, which covers a major portion of the famous North China Plain (NCP) (Liu et al., 2019). The dominant cropping practice in this region is the winter wheat-summer maize double cropping scheme, involving rotary tillage as general tillage practice (Zhao and Yang, 2018). The HHH plain contributes about $60 \%-80 \%$ of China's wheat and $40 \%$ of maize production annually; however, in recent years the climate has become warmer and drier, resulting in acute water shortage as a major agricultural constraint in this region (Jin et al., 2009; Wang et al., 2012). Due to the gradual temperature rise and uneven rainfall patterns, the summer maize in $\mathrm{HHH}$ often encounters drought events. Therefore, about $70 \%$ of the irrigation needs are met through ground and surface water resources to complement the precipitation contribution (Zhao et al., 2018). Because of the limiting agricultural water resources and increasing food insecurity, many researchers are focusing on ways to meet crop water needs as well as preserve water from losses to achieve environment-friendly and high-yield production systems.

Among various field management options, the use of mulch in agriculture has been extensively adapted as it potentially improves soil condition by reducing evaporation, moderating soil temperature regime, improving soil nutrient pools, facilitating soil microbiota and improving soil physical properties (An et al., 2015, Naab et al., 2015; Xiukang et al., 2015; Wang et al., 2019). The most common materials used as mulches are conventional organic stuff such as crop residue and crop cover and widely used plastic 
films such as low-density polyethylene (LDPE) film for high-value commercial crops (Dong et al., 2009; Zhao et al., 2010; Dlamini et al., 2016; Fan et al., 2017; Deng et al., 2019; Chang et al., 2020). Recently, researchers are making efforts to replace plastic mulches with biodegradable film or spray mulches (Immirzi et al., 2009; Li et al., 2012; Touchaleaume et al., 2016; Sartore et al., 2018). The effects of mulching, especially on soil thermal regime, vary for various kinds of mulch materials as well as for other climatic and edaphic factors. Mulches can have warming or cooling effects depending on the radiometric properties of the mulching material as they change the radiation and energy balance of the system. In general, mulches increase the soil temperature in cool weather and decrease it in hot spells. Vegetative mulches such as crop residue usually lower the daytime soil temperature but enhance it at night and early morning hours (Acharya et al., 2018). However, other factors such as soil wetness, the period of the year, rate or thickness of the residue mulch, and decomposition rate all influence the impact of residue mulch on soil thermal regime. Although plastic mulches are widely used due to their effectiveness and commercial viability, particularly in high-value crops, they pose serious challenges to the environment. Crop residue mulch is an eco-friendly and inexpensive approach, which is easy to use and causes significant crop yield improvements. The primary purpose of straw mulch is to decrease the water runoff during rain, increase the soil water infiltration, and reduce excessive evaporation (Wang et al., 2016; Yu et al., 2018). Moreover, the buffering effect of straw mulch on soil temperature can protect the crop from unwanted temperature regimes, especially at the earlier growth stages (Deng et al., 2019). However, the efficiency of crop residue mulch depends on various factors including the amount of straw mulch, time of application, and the tillage options (Wang et al., 2019). All these afore-mentioned benefits due to the mulch application ultimately increase the crop yields due to favourable soil conditions and with improved water use efficiency (Zhang et al., 2017).

Easy application and cheaper cost, with associated benefits, make crop residues perfectly applicable mulch for irrigated cropping systems as well (Akhtar et al., 2018). As described above, the primary sources of irrigation in the $\mathrm{HHH}$ region are groundwater and precipitation (Tao et al., 2015), and these resources are depleting at a faster pace. Therefore, the water and soil conservation practice of applying crop residue mulch can be effectively adopted in the $\mathrm{HHH}$ region to maximise the crop yields and most importantly improving the water use efficiency (Yin et al., 2017). This approach of previous crop straw mulching can be a potential way to handle the crop straw after harvest in China where the handling of leftover straw of major cereal crops is currently a challenging problem. A reason for the improper straw utilisation is the limited crop-livestock mixed agriculture practice in the country, and the straw cannot be utilised for animal feed. Therefore, the farmers generally are used to burn the straw after its harvest; however, recently there is a strict ban on straw burning in China (Xiao, 2012). Previous studies have documented the direct linear relationship between the straw incorporation and the soil carbon stock and organic matter (Akhtar et al., 2018; Dong et al., 2018). The present study was aimed to evaluate the wheat straw mulching in irrigated maize to check whether it improves the maize performance and its productivity by improving the soil conditions in the northern $\mathrm{HHH}$ region. The results may serve as a reference for left-over straw management effects on maize growth in $\mathrm{HHH}$ plain.

\section{Materials and methods}

\section{Experimental site description}

The field experiment was conducted during 2016 at the Science and Technology Demonstration Garden of the Chinese Academy of Agricultural Sciences in Langfang, Hebei Province, China $\left(39^{\circ} 07^{\prime} \mathrm{N}, 116^{\circ} 23^{\prime} \mathrm{E}\right.$; $9 \mathrm{~m}$ altitude). This area is characterised as the northern valley of the Huang-Huai-Hai region in China, having a warm-temperate continental monsoon climate. The general cropping practice in the region is the winter wheat summer maize. The annual mean temperature is $12^{\circ} \mathrm{C}$ and the annual mean rainfall is $556 \mathrm{~mm}$, with maximum rainfall span from June to September. The soil at the experimental site is sandy loam having $13.3 \mathrm{~g} \mathrm{~kg}^{-1}$ organic matter content, $1.4 \mathrm{~g} \mathrm{~kg}^{-1}$ total nitrogen content, $46 \mathrm{mg} \mathrm{kg}^{-1}$ available nitrogen, $14.6 \mathrm{mg} \mathrm{kg}^{-1}$ rapidly available phosphorus, $62 \mathrm{mg} \mathrm{kg}^{-1}$ rapidly available potassium, and a $\mathrm{pH}$ of 7.6.

\section{Experimental design and field operations}

In 2016, a summer maize hybrid (Zhongdan-909) was sown on $24^{\text {th }}$ June (flat sowing) by hand planters at appropriate depth with two seeds per hill. The previous crop was wheat which was harvested manually at ground level. During the land preparation, rotary tillage was performed ( $15 \mathrm{~cm}$ deep) to pulverize the soil, as the rotary tillage is general practice in this region. NPK fertilisers were applied at the rates of $200 \mathrm{~kg} \mathrm{~N} \mathrm{ha}^{-1}, 60 \mathrm{~kg} \mathrm{P}_{2} \mathrm{O}_{5} \mathrm{ha}^{-1}$, and 80 $\mathrm{kg} \mathrm{K}_{2} \mathrm{O}$ ha $^{-1}$. All $\mathrm{P}$ and $\mathrm{K}$ fertilisers were applied at sowing, whereas two equal splits of nitrogen were applied, at sowing and eightleaf stages. At the three-leaf stage, all the plots were thinned to one healthy plant per hill. The planting density was maintained at 75,000 plants ha $^{-1}$ approximately by keeping the inter-plant and inter-row distance of 0.22 and $0.60 \mathrm{~m}$, respectively. Two treatments were established on the $2^{\text {nd }}$ day after sowing, one without wheat straw mulch (NM) as control, and the other by adding wheat straw as mulch $(\mathrm{SM})$ at the rate of $5 \mathrm{Mg} \mathrm{ha}^{-1}$. The straw for mulching was used from the nearby wheat fields, where the straw residue was available in the partially crushed form due to crop harvest by combine-harvester in the $1^{\text {st }}$ week of June 2016.

The experimental design was randomised complete block design (RCBD), with five experimental replications. Each plot was $6 \mathrm{~m}$ long and $4.8 \mathrm{~m}$ wide having 8 crop rows. During the application of wheat straw mulch to the designated treatment plots, the weighing balance was used to determine the straw quantity prior to uniform spreading in plots. Irrigation was done within $24 \mathrm{~h}$ after sowing through plastic tape pipes laid down on the ground surface at equal distances having holes on them in a spiral fashion, which resulted in irrigation similar to the surface flooding approach. Two irrigations were applied, each $35 \mathrm{~mm}$ approximately, at sowing and at eight-leaf stage immediately after fertiliser application. However, the summer maize production in this region is generally dependent on summer rains, as the annual rainfall pattern matches the summer maize period which lasts from June to October. All the plots were managed well, cultural operations were conducted as recommended for the experiment area. Pre-emergence weedicides were applied at first irrigation and insecticides were applied as per general recommendation. No water stress was observed during the maize season. 


\section{Measurements and calculations}

\section{Crop growth parameters}

Germination count was performed regularly starting from the $5^{\text {th }}$ day after sowing until the constant count. During the maize growing season, each developmental stage was recognised, according to standard staging system, when more than half of the maize plants in a plot had reached that stage (Ritchie et al., 1993). Plant sampling was done at V6, V12, R1, R5, and R6 stages for leaf area and dry matter determination. Three plants were randomly selected from the destructive sampling region in each plot excluding the border rows. After harvesting plants, the leaf area (LA) was calculated by recording length and the maximum width of each green leaf, and the following equation was used (Montgomery, 1911):

LA $=$ length $\times$ maximum width $\times 0.75$

After leaf area measurements, for dry matter accumulation (DMA) the sampled plants were divided into different plant organs (leaves, stems, sheaths, ears, and ear-husks), chopped down to small pieces, and packed in Kraft paper bags for oven drying, initially at $105^{\circ} \mathrm{C}$ for $30 \mathrm{~min}$ and then at $70{ }^{\circ} \mathrm{C}$ to a constant weight.

Leaf area index (LAI) was determined as:

$\mathrm{LAI}=\mathrm{LA} \times \mathrm{PD} / 10,000$

where PD is the planting density (plants ha ${ }^{-1}$ ).

Leaf area duration (LAD) was calculated as (Hunt, 1990):

$\mathrm{LAD}=\left(\mathrm{L}_{1}+\mathrm{L}_{2}\right)\left(t_{2}-t_{1}\right) / 2$

where $\mathrm{L}_{1}$ and $\mathrm{L}_{2}$ are the leaf two consecutive leaf areas during crop season, and the $t_{1}$ and $t_{2}$ are the sampling times for both leaf areas, respectively.

Unit leaf rate (ULR) was calculated as (Hunt, 1990):

$\mathrm{ULR}=\left(\mathrm{W}_{2}-\mathrm{W}_{1}\right) /\left(t_{2}-t_{1}\right) \times\left(\log _{\mathrm{e}} L_{\mathrm{A} 2}-\log _{\mathrm{e}} L_{\mathrm{A} 1}\right) /\left(L_{\mathrm{A} 2}-L_{\mathrm{A} 1}\right)$

where $\mathrm{W}_{1}$ and $\mathrm{W}_{2}$ are the plant biomass at sampling time $t_{1}$ and $t_{2}$, respectively.

Crop growth rate (CGR) was calculated as (Hunt, 1990):

$\mathrm{CGR}=(1 / P) \times\left(\mathrm{W}_{2}-\mathrm{W}_{1}\right) /\left(t_{2}-t_{1}\right)$

SPAD values were recorded as a function of leaf chlorophyll content at VT, R1, R2, R3, R5, and R6 stages, for all the treatment plots. SPAD meter (SPAD-502; Konica Minolta, Japan) was used to record the chlorophyll readings, three plants from each plot were sampled for ear leaf, the third leaf from the top (tassel position) and fourth leaf downwards from the apical ear. Each leaf was sampled at three points on the leaf blade (excluding mid-rib) viz. tip of the leaf, middle, and the start of leaf-blade, then the average of three values was used.

\section{Soil temperature and moisture content}

Soil water contents were determined by the gravimetric method for two soil depths $(0-15 \mathrm{~cm} \& 15-30 \mathrm{~cm})$ from each plot at V6, V12, VT, R1, R3, and R5 stages during the maize season. Samples were obtained from the random points in a plot at the centre of two maize rows, using soil cores with $5 \mathrm{~cm}$ diameter. Soil moisture content (SMC, $\mathrm{g} \mathrm{g}^{-1}$ ) was calculated as the weight difference between the fresh and oven-dried $\left(105^{\circ} \mathrm{C}\right.$ for $\left.36 \mathrm{~h}\right)$ samples.

Soil temperature was recorded on the same day as the soil moisture content viz. V6, V12, VT, R1, R3, and R5 stages for all the experimental plots. Soil temperature was measured by a threepronged $5 \mathrm{~cm}$ long sensor using Decagon's 5TE soil sensor (Decagon 5TE VWC, Temp + EC, Decagon Devices Inc.). The soil temperature was recorded on a sunny day at 12:00 hr noon for the two soil depths $(0-15 \mathrm{~cm}$ and $15-30 \mathrm{~cm})$.

\section{Yield and yield components}

Maize was manually harvested on $28^{\text {th }}$ October 2016 upon the appearance of black layer at the kernel juncture (physiological maturity), by selecting four 4-m long central rows (no previous sampling) comprising a total harvest area of $9.6 \mathrm{~m}^{2}$ in each plot. All the ears, including prolific and non-prolific, were counted for the selected harvest area to determine the number of ears per hectare. On the day of harvest, ten random plants from the harvest area were tagged and manually cut at the ground-level. Immediately after harvesting, the fresh weights of ten plants were recorded with and without the ears, then three representative plants were chopped into pieces and ovendried (initially at $105^{\circ} \mathrm{C}$, then at $70^{\circ} \mathrm{C}$ ) till the constant weight achieved to determine the dry biomass yield. The removed ears from ten plants (excluding ear husks) were packed in plastic mesh bags and sun-dried before determining the grain yield and yield components (kernels per ear, 1000-kernel weight). After processing these ten plants, the ears were harvested manually from the remaining marked harvest area $\left(9.6 \mathrm{~m}^{2}\right)$ in each plot and sun-dried before final yield determination. Kernels number per ear and the thousand kernel weight (after oven-dried at $70^{\circ} \mathrm{C}$ ) were calculated as the mean value from ten ears. The final grain yield calculation was done at $15 \% \mathrm{ker}-$ nel moisture content. Kernel moisture content (\%) was measured by Instant Multiple Moisture Tester PM-650 (KETT Electric Co. Japan).

\section{Statistical analysis}

Data regarding no-mulch and wheat-straw mulch treatments were subjected to ANOVA test, and Pairwise comparisons of significant effects were conducted using Tukey's HSD post hoc tests, with significant differences identified where $\mathrm{P}<0.05$. Statistical

Table 1. Grain yield, ear number, kernels number, thousand kernels weight, harvest index, biomass yield and shelling percentage of summer maize under wheat straw mulch and no-mulch treatments in Northern Huang-Huai-Hai region of China.

\begin{tabular}{|c|c|c|c|c|c|c|c|c|}
\hline Treatment & $\begin{array}{l}\text { Grain } \\
\text { yield } \\
\mathrm{Mg} \mathrm{ha}^{-1}\end{array}$ & $\begin{array}{c}\text { No. of } \\
\text { ears } \\
\mathrm{m}^{-2}\end{array}$ & $\begin{array}{l}\text { No. of } \\
\text { kernels } \\
\text { ear }^{-1}\end{array}$ & $\begin{array}{l}\text { No. of } \\
\text { kernels } \\
\mathrm{m}^{-2}\end{array}$ & $\begin{array}{c}\text { 1000-kemel } \\
\text { weight } \\
\text { g }\end{array}$ & H-index & $\begin{array}{l}\text { Total dry } \\
\text { biomass } \\
\text { Mg ha }^{-1}\end{array}$ & $\begin{array}{c}\text { Shelling } \\
\text { percentage } \\
\%\end{array}$ \\
\hline No-mulch & $9.9 \pm 0.06$ & $7.2 \pm 0.11$ & $387 \pm 9.5$ & $2798 \pm 53$ & $295 \pm 3$ & 0.562 & $15 \pm 0.2$ & $84.8 \pm 0.1$ \\
\hline Mulch & $11.7 \pm 0.17$ & $7.5 \pm 0.05$ & $454 \pm 8.5$ & $3194 \pm 37$ & $317 \pm 4$ & 0.561 & $18 \pm 0.3$ & $85.2 \pm 0.5$ \\
\hline P-value & 0.004 & 0.035 & 0.022 & 0.044 & 0.058 & 0.967 & 0.002 & 0.556 \\
\hline
\end{tabular}

The values show mean \pm standard error. 
analyses were done using software Statistics 8.1 (Analytical Software Inc., USA), and graphs were generated using OriginLab, version 2018.

\section{Results}

\section{Grain yield and yield components}

Wheat straw mulch significantly $(\mathrm{P}<0.05)$ affected the maize grain yield and the yield components compared to no-mulch treatment (Table 1). With the straw mulch treatment, grain yield was recorded at $11.7 \mathrm{Mg} \mathrm{ha}^{-1}$ which was $18 \%$ greater than the nomulch treatment. The increase in grain yield for mulching treatment was supported by better yield components. Kernels number per ear and kernels number per area were found significantly greater for the straw mulch treatment compared to no-mulch. Kernels number per ear for the straw mulch maize were $17.3 \%$ greater than the no-mulch maize (Table 1). Similarly, the number of kernels per area were also recorded greater (14\%) for the mulch treatment as compared to no-mulch. However, there was no significant difference found between the mulch and no-mulch treatments for thousand kernels weight (Table 1). Total dry biomass yield for mulch treatment was $18 \mathrm{Mg} \mathrm{ha}^{-1}$ and for no-mulch treatment, it was recorded at $15 \mathrm{Mg} \mathrm{ha}^{-1}$. No significant difference was record- ed for harvest index and shelling percentage between the two treatments (Table 1).

\section{Maize growth attributes and dry matter accumulation}

Maize growth attributes were also affected significantly throughout the growth period (except initial vegetative stages) and at the final maturity stage as well. LAI for mulch and no-mulch maize differed greatly $(\mathrm{P}<0.05)$ at $\mathrm{V} 12, \mathrm{R} 1$, and $\mathrm{R} 5$ stages, with the mulch treatment having greater LAI compared to no-mulch treatment (Figure 1). Maximum LAI was recorded at the flowering stage for mulch treatment. Similarly, the green leaf area duration was also recorded maximum for mulch treatment at later reproductive stages, compared to the no-mulch treatment (Figure 1). Unit leaf rate was significantly greater at the early growth stages of V6$\mathrm{V} 12$ as well as at later reproductive stages for the mulch treatment compared to no-mulch treatment (Figure 1). Regarding the CGR, mulch treatment had a vigorous growth rate during the V6-V12 interval, and subsequently at later stages of reproduction. However, the decline in growth rate was observed after the R1 stage till the maturity for the no-mulch treatment (Figure 1).

Dry matter accumulation rate for both mulch and no-mulch treatments was greater at the post-silking stage compared to the pre-silking period (Figure 2). However, the total dry matter accumulation $\left(\mathrm{g} \mathrm{plant}^{-1}\right)$ at maturity was greater for mulch treatment as compared to no-mulch. Figure 2 shows the dry matter partitioning

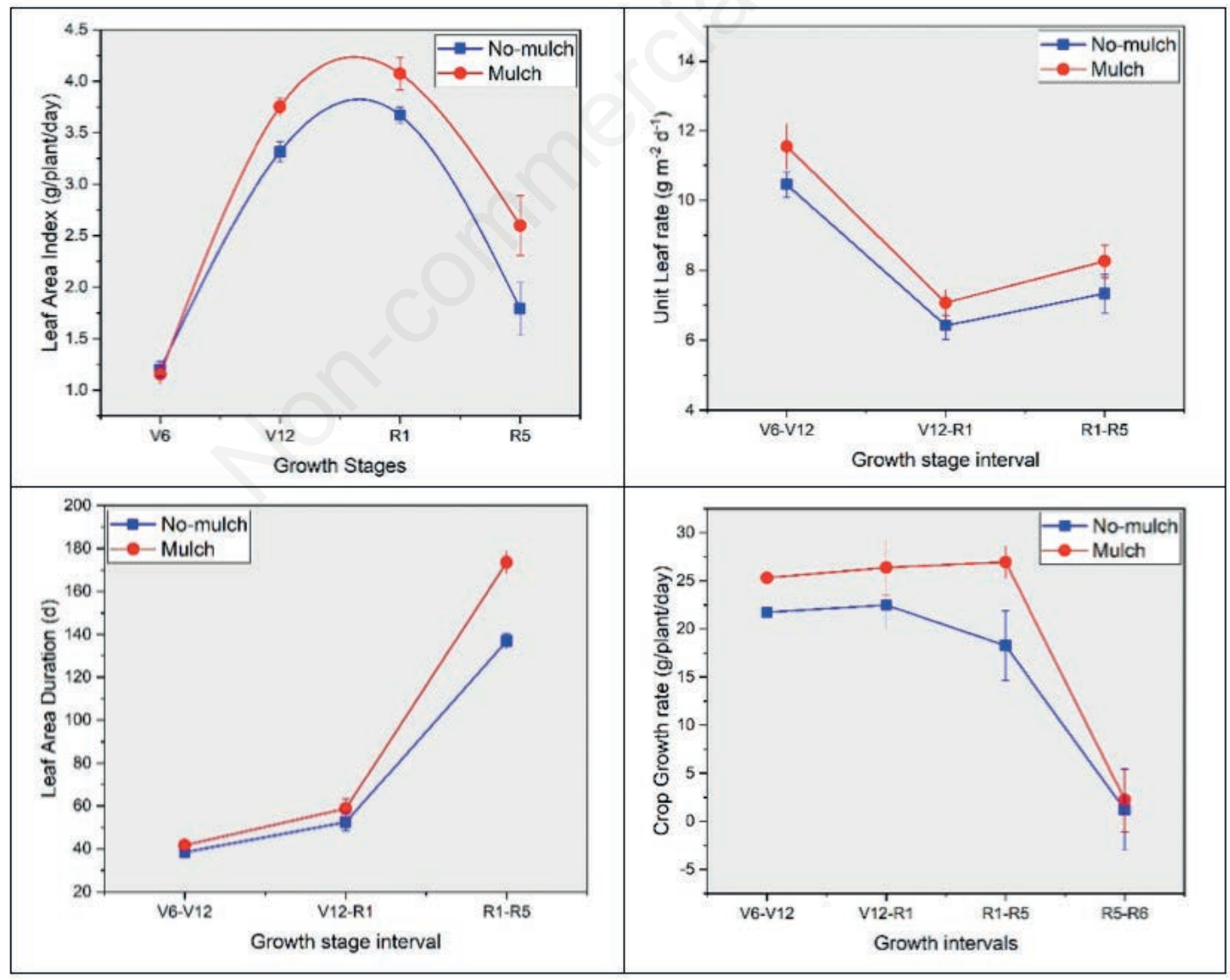

Figure 1. Effect of wheat straw mulch and no-mulch treatments on leaf area index (LAI), unit leaf rate (ULR), leaf area duration (LAD), and crop growth rate (CGR) of summer maize in Northern Huang-Huai-Hai region of China. 
among different plant organs i.e. leaves, stems, leaf sheaths, ears, and ear-husks (including tassels); and the maximum partitioning, as expected, was in maize kernels followed by stems. At the maturity stage (R6), dry matter partitioning for maize kernels was maximum (175 g) for mulch treatment as compared to no-mulch (149 g) (Figure 2). Similarly, the stem dry matter was greater for mulch treatment, which was $43.5 \mathrm{~g}$ for mulch treatment and $33 \mathrm{~g}$ for nomulch. The significant difference in dry matter partitioning was observed in post-flowering stages. SPAD values for both treatments also showed significant differences at post-silking stages for various leaf strata (Figure 3). SPAD values of ear leaf for mulch treatment at R1 and R5 stages were respectively 62.6 and 55.2 compared to 59.3 and 51.6 for no-mulch treatment. However, the third leaf below the ear-leaf showed greater differences for both treatments at R3, R5, R6 stages (later maturity stages) with SPAD values of respectively 43, 29, 16 for no-mulch and 50, 45, 32 for mulch treatment (Figure 3 ). Plant height also varied significantly $(\mathrm{P}<0.05)$ for mulch and no-mulch treatments. Mulch treatment was recorded with a greater final plant height of $278 \mathrm{~cm}$, compared to $263 \mathrm{~cm}$ recorded for no-mulch treatment (Figure 4).

A

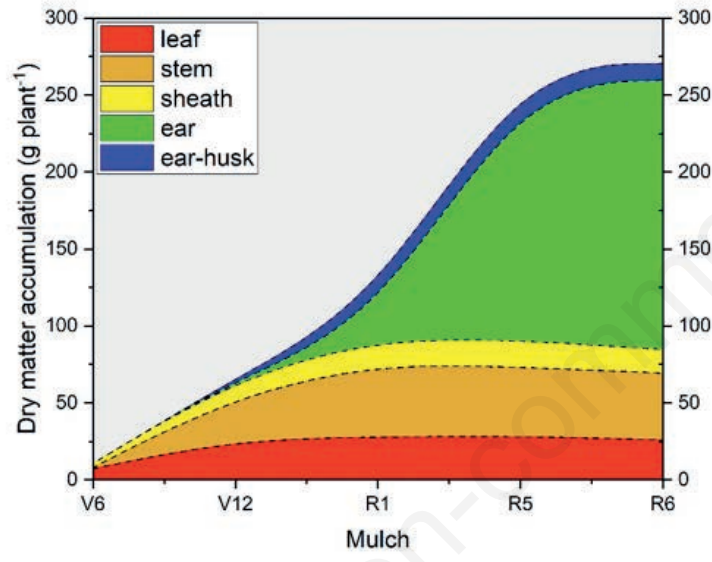

B

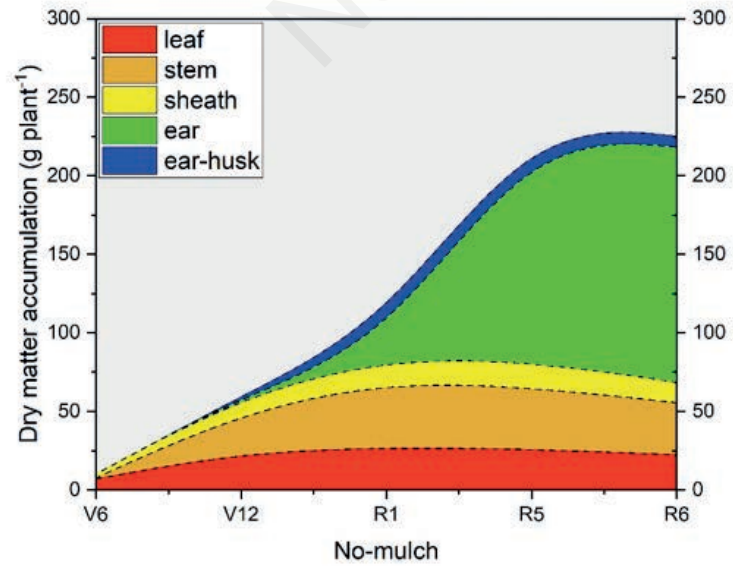

Figure 2. Effect of wheat straw mulch (A) and no-mulch (B) treatments on dry matter partitioning in different plant organs of summer maize in Northern Huang-Huai-Hai region of China.

\section{Soil moisture and soil temperature}

Mulch and no-mulch treatments varied significantly at respective growth stages for soil moisture and soil temperatures at different depths (Figures 5 and 6). Maximum soil moisture was observed for mulch treatment at R3 growth stage, which was $21.6 \%$ at $0-15$ $\mathrm{cm}$ soil depth and $22.4 \%$ for $15-30 \mathrm{~cm}$ soil depth (Figure 5). In contrast, the minimum soil moisture contents were recorded for no-mulch treatment at V6 stage, which was $15.8 \%$ at $0-15 \mathrm{~cm}$ soil depth. Regarding the soil temperature, results showed that mulch treatment significantly decreased the day-time soil temperature relative to no-mulch treatment for both soil depths (Figure 6). On average, mulching treatment reduced the average soil temperature by $1.9^{\circ} \mathrm{C}$ for top-soil $(0-15 \mathrm{~cm})$ and $1.5^{\circ} \mathrm{C}$ for below-surface soil $(15-30 \mathrm{~cm})$ during the crop period. Primarily, the mulching treatment showed wider differences for upper and lower soil depths during the initial growth stages (V6, V12, VT) compared to later reproductive stages. Compared to no-mulch treatment, the decreases in soil temperature under mulch treatment at V6, V12, VT, R1, $\mathrm{R} 3$, and R5 stages were respectively $2.4,2.6,1.8,2.9,1.6$ and $0.4^{\circ} \mathrm{C}$ for $0-15 \mathrm{~cm}$ soil layer and $1.6,1.8,2.3,1.2,1.0$ and $1.1^{\circ} \mathrm{C}$ for $15-30 \mathrm{~cm}$ soil layer (Figure 6).

A

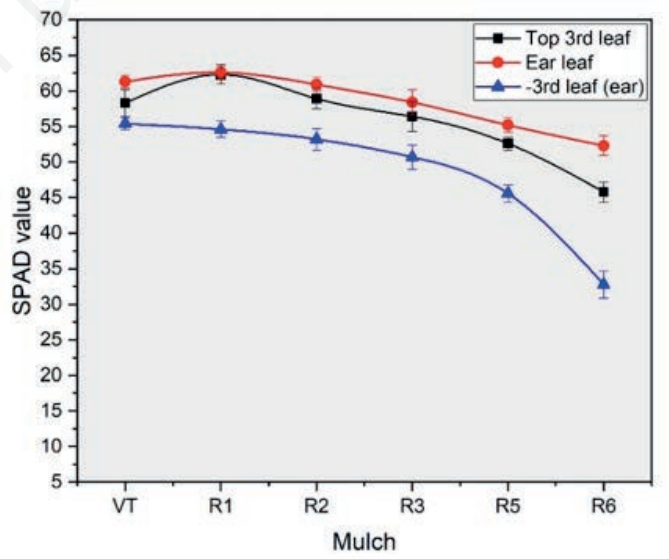

B

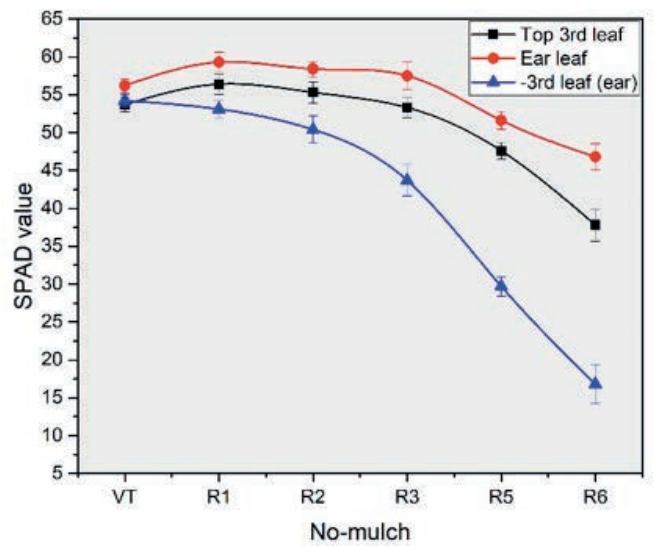

Figure 3. Changes in SPAD readings of different leaves (top $3^{\text {rd }}$ leaf, ear leaf, $3^{\text {rd }}$ leaf below ear) of summer maize under wheat straw mulch (A) and no-mulch (B) treatments in Northern Huang-Huai-Hai region of China. 


\section{Discussion}

\section{Straw mulch improves maize yield and growth parameters}

Population increase at a higher pace and limiting water resources are posing serious threats to food security. Mulching is a cheap practice to improve the soil health and to preserve the soil water contents in the drought-prone farmlands (Yin et al., 2017; Wang et al., 2019). Optimum temperature and soil moisture are the key requirements for the normal growth of crop plants (Wu et al., 2016). Use of mulch materials has been extensively adapted in the arid lands of China, as a measure to sustain the soil with maximum available water contents, thus ensuring the increased maize productivity (Wang et al., 2016; Yu et al., 2018). In the present study, wheat straw mulch has greatly improved the maize performance and soil status in the northern $\mathrm{HHH}$ region of China, compared to no-mulch treatment. Improved maize performance under mulch treatment was observed as increased grain yields, kernels number per ear and per area, greater LAI, LAD, ULR, and CGR. Under arid conditions, yield increase in maize under straw and plastic mulch was also attributed mainly due to improved LAI dynamics, and due to increased kernels number per ear (Yin et al., 2017). Better growth parameters for mulch maize might be attributed to the favourable soil conditions with greater soil moisture contents and improved soil temperature during the various growth stages (Wu et al., 2016). Straw mulch is reported to have more beneficial effects in restoring soil moisture as compared to the plastic mulch because straw mulch allows more water infiltration for in-season rainfall and plastic mulch favours runoff more compared to infiltration (Qin et al., 2013). Recently, Li et al. (2018) reported their findings for 7-year straw mulching with tillage practices in China, where a significant increase in crop yields was observed due to straw incorporation compared to no straw mulch, and additionally, straw mulch also improved soil organic carbon and soil moisture at different soil depths. Increase in crop productivity is also coupled with improved water use efficiency (WUE) for maize crop under straw mulch alone or in combination with plastic film mulch, as the mulch material reduces soil water evaporation during early stages (Li et al., 2018a; Li et al., 2018b).

Favourable soil conditions under mulch material were reflected in

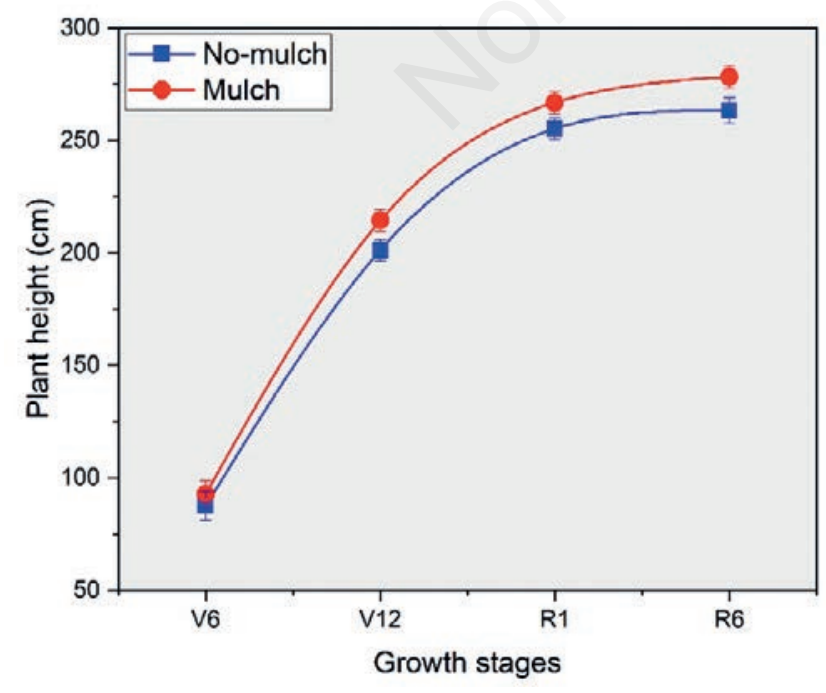

Figure 4. Effect of wheat straw mulch and no-mulch treatments on plant height at different growth stages of summer maize in Northern Huang-Huai-Hai region of China. the vigorous growth of maize plants in the present study, with higher leaf area over land area, greener leaves with higher SPAD values, and longer duration of green leaves. Higher green leaf area in mulch treatment coupled with greater carbohydrate assimilation rate, as is shown by greater unit leaf rate in mulch treatment compared to no-mulch. These findings are in agreement with that of Yin et al. (2017), where the yield increments (up to 17\%) were recorded due to increase in LAI and increased number of maize ears and kernel weights. Crop residue mulching and plastic mulching have also been reported to improve the soil organic carbon and nitrogen fractions in the top-soil $(0-10 \mathrm{~cm})$, which caused a significant increase in maize yield in China (Dong et al., 2018). Similarly, Akhtar et al. (2018) also found an increase in SOC and available $\mathrm{N}$ content due to wheat straw mulch in maize crop.
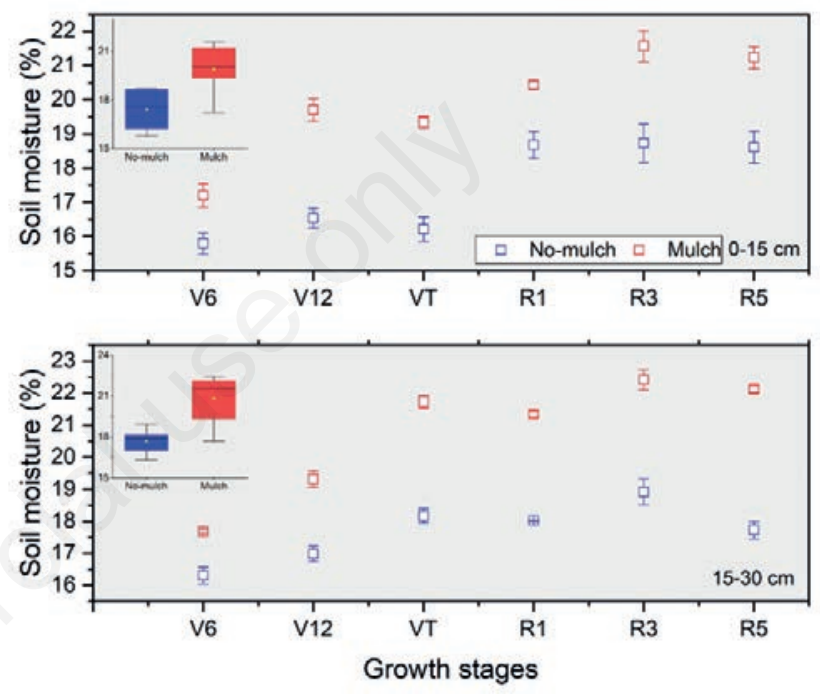

Figure 5. Changes in soil moisture content in different soil layers $(0-15 \mathrm{~cm}, 15-30 \mathrm{~cm})$ during summer maize growing season under wheat straw mulch and no-mulch treatments in Northern Huang-Huai-Hai region of China.
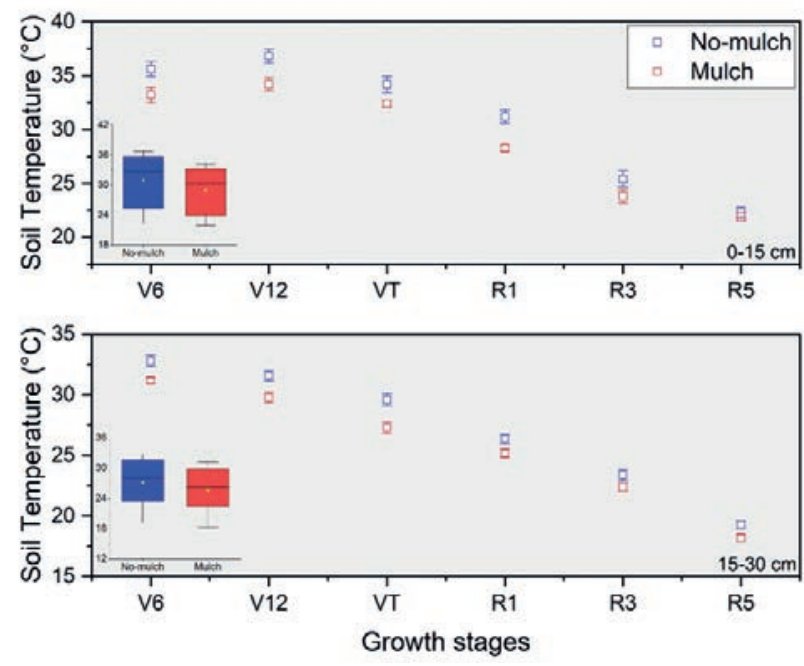

Figure 6. Changes in soil temperature in different soil layers ( 0 $15 \mathrm{~cm}, 15-30 \mathrm{~cm}$ ) during summer maize growing season under wheat straw mulch and no-mulch treatments in Northern Huang-Huai-Hai region of China. 
Table 2. Weather conditions at Langfang experimental station of Chinese Academy of Agricultural Sciences, Hebei province during the summer maize growing season in 2016.

\begin{tabular}{lccccc} 
Crop months (2016) & $\begin{array}{c}\text { Mean temperature } \\
\left({ }^{\circ} \mathrm{C}\right)\end{array}$ & $\begin{array}{c}\text { Maximum temperature } \\
\left({ }^{\circ} \mathrm{C}\right)\end{array}$ & $\begin{array}{c}\text { Minimum temperature } \\
\left({ }^{\circ} \mathrm{C}\right)\end{array}$ & $\begin{array}{c}\text { Precipitation } \\
(\mathrm{mm})\end{array}$ & $\begin{array}{c}\text { Sunshine } \\
\text { hours }\end{array}$ \\
June & 25.14 & 31.51 & 18.70 & 87 & 228.4 \\
July & 26.62 & 31.72 & 22.24 & 254.9 & 135.9 \\
\hline August & 25.77 & 30.81 & 21.22 & 52.5 & 207.7 \\
September & 20.87 & 27.51 & 15.49 & 17.6 & 220.3 \\
\hline October & 12.72 & 18.46 & 8.17 & 39.4 & 119.7 \\
\hline
\end{tabular}

\section{Straw mulching affects soil moisture content and soil tem- perature}

Maize crop is sensitive to temperature extremes during early growth season as well as late reproductive stages, which normally delay the crop growth period (Liu et al., 2009; Bu et al., 2013). In this study, average soil temperature was lower under mulch treatment compared to no-mulch for summer maize. Radiometric properties of the mulch material and heat conduction between the mulch and the soil surface drive the ability of mulch to moderate soil temperature (Bavougian et al., 2018). Vegetative or organic mulches reduce the heat conduction into and out of the soil, causing cooler soil during the day but warmer soil at night compared to bare soil (Acharya et al., 2018). Straw mulch in present study lowered the daytime soil temperature, and an average decrease of 1.9 and $1.5^{\circ} \mathrm{C}$ was observed for top and subsoils during the crop period, respectively. This decrease was in line with earlier studies reporting lower soil temperature under straw mulch treatment (Fourie and Freitag, 2010; Gholamhuseini et al., 2019); however, Bavougian et al. (2018) reported increased soil temperature under organic mulch suggesting increased microbial activity as a possible reason. Summers et al. (2004) found that wheat straw reflected approximately $85 \%$ of the visible spectrum of light compared to $41 \%$ under bare soil. However, reflection is usually greater from bright residues and decreases as straw ages (discoloration) and decomposes, resulting in temperature differences between mulch and bare soil to diminish over time (Acharya et al., 2018). Our results also showed diminishing soil temperature differences over time, especially during late reproductive stages from the R1 stage onwards. The maximum temperature difference at this stage $(\mathrm{R} 1)$ was recorded $2.9^{\circ} \mathrm{C}$ for top soil, compared to a difference of only $0.4^{\circ} \mathrm{C}$ at the $\mathrm{R} 5$ stage, suggesting that the reduction in soil temperature was more prominent for the initial growth stages (up to 60 days after sowing) as well as for top soil compared to subsoil (Figure 6). Decrease in soil temperature during early stages and reduced diurnal fluctuation in the present study facilitated more favourable temperature regimes for maize seedling and hence positively influenced crop growth. Recently, Deng et al. (2019) also demonstrated the similar effects of mulch material on soil temperature, where the temperature difference was greater in the upper soil layers as compared to the below soil and there was a gradual decrease in this trend at the successive growth stages of maize. The underlying mechanism behind the decrease in soil temperature due to straw mulch could be explained by the buffering action of straw between the solar radiation and thermal radiation of earth, thereby preventing the thermal exchange between both layers.

Straw mulch greatly increased the capacity of soil to uphold the moisture contents in the topsoil $(0-15 \mathrm{~cm})$ and below layers $(15-30 \mathrm{~cm})$ as well, the reasons might be the reduced soil evaporation due to mulch cover as compared to bare soil with no mulch covering ( $\mathrm{Li}$ et al., 2018a; Li et al., 2018b). Therefore, sufficient soil moisture and temperature are both the vital components for optimum root growth, nutrient uptake, and better soil health. It is evident from the present study that most of the rainfall ( $\sim 300 \mathrm{~mm}$ ) occurred during July (Table 2$)$, and in that scenario, the straw mulch helped increase the infiltration and it also provided a barrier to water loss through soil evaporation. In the $\mathrm{HHH}$ region, the maximum rainfall season coincides with the summer maize growing season. Moreover, summer maize has more favourable conditions with a greater number of sunshine hours compared to spring maize (Table 2), therefore maize plants can utilise the light and soil resources to their maximum for higher grain yields (Tang et al., 2018).

\section{Conclusions}

Wheat straw mulching proved to be a viable approach in improving irrigated maize productivity through modulating soil moisture and soil temperature, compared to no mulch. Straw mulch increased the soil moisture contents during the crop growth period and lowered the soil temperature $\left(\sim 1.72^{\circ} \mathrm{C}\right)$ in the surface and sub-surface soil layers and favoured the maize growth during initial stages with better growth indices. Yield increase for the mulch treatment was mainly attributed due to greater dry biomass yield, kernels number per ear, and kernels number per area in comparison with no mulch. Therefore, straw mulch can be practiced as a sustainable agronomic approach in improving soil conditions and consequently the maize productivity under irrigated conditions.

\section{References}

Acharya CL, Bandyopadhyay KK, Hati KM, 2018. Mulches: role in climate resilient agriculture, reference module in earth systems and environmental sciences. Available from: krishi.icar.gov.in

Akhtar K, Wang W, Ren G, Khan A, Feng Y, Yang G, 2018. Changes in soil enzymes, soil properties, and maize crop productivity under wheat straw mulching in Guanzhong, China. Soil Till. Res. 182:94102.

An T, Schaeffer S, Li S, Fu S, Pei J, Li H, Zhuang J, Radosevich M, Wang J, 2015. Carbon fluxes from plants to soil and dynamics of microbial immobilisation under plastic film mulching and fertilizer application using 13C pulse-labeling. Soil Biol. Biochem. 80:53-61.

Bavougian CM, Read PE, 2018. Mulch and groundcover effects on soil temperature and moisture, surface reflectance, grapevine water potential, and vineyard weed management. PeerJ 6:e5082.

Bu L-D, Liu J-L, Zhu L, Luo S-S, Chen X-P, Li S-Q, Lee Hill R, Zhao $Y, 2013$. The effects of mulching on maize growth, yield and water use in a semi-arid region. Agric. Water Manag. 123:71-8.

Chang L, Han F, Chai S, Cheng H, Yang D, Chen Y, 2020. Straw strip mulching affects soil moisture and temperature for potato yield in semiarid regions. Agron. J. 112:1126-39.

Deng H-L, Xiong Y-C, Zhang H-J, Li F-Q, Zhou H, Wang Y-C, Deng Z-R, 2019. Maize productivity and soil properties in the Loess 
Plateau in response to ridge-furrow cultivation with polyethylene and straw mulch. Sci. Rep. 9.

Dong H, Li W, Wei T, Zhang D, 2009. Early plastic mulching increases stand establishment and lint yield of cotton in saline fields. Field Crops Res. 111:269-75.

Dong QG, Yang Y, Yu K, Feng H, 2018. Effects of straw mulching and plastic film mulching on improving soil organic carbon and nitrogen fractions, crop yield and water use efficiency in the Loess Plateau, China. Agric. Water Manag. 201:133-43.

Dlamini P, Ukoh IB, van Rensburg LD, du Preez CC, 2016. Reduction of evaporation from bare soil using plastic and gravel mulches and assessment of gravel mulch for partitioning evapotranspiration under irrigated canola. Soil Res. https://doi.org/10.1071/SR16098

Fan Y, Ding R, Kang S, Hao X, Du T, Tong L, 2017. Plastic mulch decreases available energy and evapotranspiration and improves yield and water use efficiency in an irrigated maize cropland. Agric. Water Manage. 179:122-31.

Fourie JC, Freitag K, 2010. Soil management in the Breede River Valley wine grape region, South Africa. 2. Soil temperature. South Afr. J. Enol. Viticult. 31:165-8.

Gholamhoseini M, Dolatabadian A, Habibzadeh F, 2019. Ridge-furrow planting system and wheat straw mulching effects on dryland sunflower yield, soil temperature, and moisture. Agron. J. 111:338392.

Hunt R, 1990. Basic growth analysis: plant growth analysis for beginners. Unwin Hyman, London, UK.

Immirzi B, Santagata G, Vox G, Schettini E, 2009. Preparation, characterisation and field-testing of a biodegradable sodium alginatebased spray mulch. Biosyst. Engine. 102:461-72.

Jin H, Qingjie W, Hongwen L, Lijin L, Huanwen G, 2009. Effect of alternative tillage and residue cover on yield and water use efficiency in annual double cropping system in North China Plain. Soil Till. Res. 104:198-205.

Li R, Hou X, Jia Z, Han Q, Yang B, 2012. Effects of rainfall harvesting and mulching technologies on soil water, temperature, and maize yield in Loess Plateau region of China. Soil Res. 50.

Li S, Li Y, Lin H, Feng H, Dyck M, 2018a. Effects of different mulching technologies on evapotranspiration and summer maize growth. Agric. Water Manag. 201:309-18.

Li Z, Lai X, Yang Q, Yang X, Cui S, Shen Y, 2018b. In search of longterm sustainable tillage and straw mulching practices for a maizewinter wheat-soybean rotation system in the Loess Plateau of China. Field Crop Res. 217:199-210.

Liu CA, Jin SL, Zhou LM, Jia Y, Li FM, Xiong YC, Li XG, 2009. Effects of plastic film mulch and tillage on maize productivity and soil parameters. Eur J. Agron. 31:241-9.

Liu Z, Gao J, Gao F, Liu P, Zhao B, Zhang J, 2019. Late harvest improves yield and nitrogen utilisation efficiency of summer maize. Field Crops Res. 232:88-94.

Montgomery E, 1911. Correlation studies in corn, Vol. 24. pp. 108-159 in Annual Report No. 24 of Nebraska Agricultural 566 Experiment Station, Lincoln, NE, USA.

Naab JB, Mahama GY, Koo J, Jones JW, Boote KJ, 2015. Nitrogen and phosphorus fertilisation with crop residue retention enhances crop productivity, soil organic carbon, and total soil nitrogen concentrations in sandy-loam soils in Ghana. Nutr Cycl Agroecosys 102:33-43.

Qin W, Chi B, Oenema O, 2013. Long-term monitoring of rainfed wheat yield and soil water at the loess plateau reveals low water use efficiency. PLoS One 8:e78828.

Ritchie S, Hanway J, Benson G, 1993. How a corn plant develops. Spec. Rep. Iowa State Univ. Coop. Ext. Serv., Ames. Special Report. 38. Available from: https://lib.dr.iastate.edu/specialre- ports $/ 38$

Sartore L, Schettini E, de Palma L, Brunetti G, Cocozza C, Vox G, 2018. Effect of hydrolyzed protein-based mulching coatings on the soil properties and productivity in a tunnel greenhouse crop system. Sci. Total Environ. 645:1221-9.

Summers CG, Mitchell JP, Stapleton JJ, 2004. Management of AphidBorne viruses and Bemisia argentifolii (Homoptera: Aleyrodidae) in zucchini squash by using Uv reflective plastic and wheat straw mulches. Environ. Entomol. 33:1447-57.

Tang L, Ma W, Noor MA, Li L, Hou H, Zhang X, Zhao M, 2018. Density resistance evaluation of maize varieties through new "Density-Yield Model" and quantification of varietal response to gradual planting density pressure. Sci. Rep. 8 .

Tao Z, Li C, Li J, Ding Z, Xu J, Sun X, Zhou P, Zhao M, 2015. Tillage and straw mulching impacts on grain yield and water use efficiency of spring maize in Northern Huang-Huai-Hai Valley. Crop J. 3:445-50.

Touchaleaume F, Martin-Closas L, Angellier-Coussy H, Chevillard A, Cesar G, Gontard N, Gastaldi E, 2016. Performance and environmental impact of biodegradable polymers as agricultural mulching films. Chemosphere 144:433-9.

Wang J, Wang E, Yang X, Zhang F, Yin H, 2012. Increased yield potential of wheat-maize cropping system in the North China Plain by climate change adaptation. Clim. Change 113:825-40.

Wang X, Fan J, Xing Y, Xu G, Wang H, Deng J, Wang Y, Zhang F, Li $\mathrm{P}, \mathrm{Li} \mathrm{Z}, 2019$. The effects of mulch and nitrogen fertilizer on the soil environment of crop plants. Adv. Agron. 153:121-73.

Wang YP, Li XG, Zhu J, Fan CY, Kong XJ, Turner NC, Siddique KHM, F-M Li, 2016. Multi-site assessment of the effects of plastic-film mulch on dryland maize productivity in semiarid areas in China. Agric. For. Meteorol. 220:160-9.

Wu Y, Huang F, Zhang C, Jia Z, 2016. Effects of different mulching patterns on soil moisture, temperature, and maize yield in a semiarid region of the Loess Plateau, China. Arid Land Res Manag. 30:490-504.

Xiao Y, 2012. The analysis of straw burning and use. J. Green Sci. Tech. 11:72-4.

Xiukang W, Zhanbin L, Yingying X, 2015. Effects of mulching and nitrogen on soil temperature, water content, nitrate-N content and maize yield in the Loess Plateau of China. Agric. Water Manag. 161:53-64.

Yin W, Zhao C, Chai Q, Guo Y, Feng F, Yu A, 2017. Effects of previous wheat straw on the yield of maize in the oasis irrigation region. Crop Sci. 57:3217.

Yin W, Zhao C, Chai Q, Guo Y, Feng F, Yu A, 2017. Effects of previous wheat straw on the yield of maize in the oasis irrigation region. Crop Sci. 57:3217.

Yu Y-Y, Turner NC, Gong Y-H, Li F-M, Fang C, Ge L-J, Ye J-S, 2018. Benefits and limitations to straw- and plastic-film mulch on maize yield and water use efficiency: A meta-analysis across hydrothermal gradients. Eur J. Agron. 99:138-47.

Zhang Q, Wang Z, Miao F, Wang G, 2017. Dryland maize yield and water-use efficiency responses to mulching and tillage practices. Agron. J. 109:1196.

Zhao J, Yang X, 2018. Average amount and stability of available agroclimate resources in the main maize cropping regions in China during 1981-2010. J. Meteorol. Res. 32:146-56.

Zhao J, Yang X, Sun S, 2018. Constraints on maize yield and yield stability in the main cropping regions in China. Eur J. Agron. 99:106-15.

Zhao W, Liu B, Zhang Z, 2010. Water requirements of maize in the middle Heihe River basin, China. Agric. Water Manage. 97:215-23. 